\title{
Investigating the relationship between service quality and customer loyalty: A case study of banking industry
}

\author{
Aliakbar Aghaei ${ }^{a}$, Mohammad Ali Mostafapour ${ }^{b^{*}}$, and Hamid Rezaei ${ }^{\text {b }}$
}

${ }^{a}$ Golestan University, Gorgan,Iran

${ }^{b}$ Department of Management and Accounting, Minoodasht Branch, Islamic Azad University, Minoodasht, Iran

\section{H R O N I C L E}

Article history:

Received January 30, 2013

Received in revised format

20 May 2013

Accepted May 282013

Available online

June 12013

Keywords:

Quality

Service Quality

Customer loyalty

Melli Bank

\section{A B S T R A C T}

The present study investigates the relationship between service quality and customer loyalty in one of Iranian banks in province of Golestan, Iran named Bank Melli Iran. The population of the study consists of all customers of this branch. Using Kersity-Morgan table and simple random sampling, a number of 384 customers were selected as the participants of the study. The method of research is descriptive-correlation with a survey design. SERVQUAL scale and a researcher-made questionnaire were used to examine service quality and customer loyalty, respectively. Pearson correlation formula was run to analyze the data. The results showed a significant relationship between different aspects of service quality and customer loyalty in this particular branch of bank.

\section{Introduction}

In the competitive world of business, high service quality plays an essential role for the success of organizations. However, we need to make sure that delivering good service quality is not a competitive strategy to be implemented by firms as a distinguishing factor rather it is considered as a critical factor for the survival and profitability of firms. Business success in the current world of economy depends entirely on the capability to build distinct product values through developing innovative product designs and introducing these innovations to the customers, effectively. Despite the quality of products which is ascertained by specified standards, the quality of services is assessed in terms of their functionality (Crosby, 2004). The degree of service quality specifies how much the service has reached or been beyond customers' expectations. In other words, service quality is associated with the level of customer satisfaction with the fulfillment of requirements, necessities and expectations. This is necessary to help distinguish among products as well as services and build a 
sense of trust and loyalty in customers. Service companies are primarily concerned with engendering loyalty in customers by improving the quality of services. Successful firms direct their attempts towards improving the quality of services based on their thoughts into customer requirements and deficiencies in their current services. When things are not accomplished, properly, they will look for relevant factors to prevent reoccurrence of failures in future. They may concentrate on innovative techniques to increase the quality of services and customer loyalty, simultaneously. Service quality is a newly-developed scientific field with over three decades of research background (Guo et al., 2008).

The term service quality may be interpreted differently by various people. Therefore, we have to shape a crystal clear definition for the concept of quality in the first place. In addition, adopting a definition of quality is not only essential but also helps direct employees' attempts towards offering high quality services. Quality is associated with providing the customer with service or product, which needs good design quality, adaptation, availability and suitability of service location. Quality could be also represented on providing customers with what they actually wish. In other words, a high quality service must correspond with the customer requirements. Therefore, quality can be described as the correspondence between services offered and customer requirements (Brady \& Joseph, 2001).

International Organization for Standardization (ISO) describes quality as all the components of a service or product to reach customers' needs. Singapore National Productivity Board indicates that it is the customer but not producer or service provider who specifies the quality. More lucidly, quality is associated with a set of service or product features, which fulfill customer requirements. Others defined quality as a broad concept where all parts of a firm are committed to improve the efficiency of the whole organization so that it would remove deterrent factors and eventually result in complete adaptation of services to the requirements specified by the customer in minimum costs. Parasuraman et al. (2000) contend that perceived quality refers to customer judgments of the superiority or advantage of a product. Perceived quality is a kind of behavior associated with, but not identical to, perfect satisfaction and can be interpreted by comparing expectations and perceived performance (Arasli et al., 2004; Babakus \& Boller, 1992; Parasuraman et al., 1985).

Hakkak and Zare (2013) investigated relationship between marketing and customer's loyalty. The study designed a questionnaire consists of three parts. The first part was associated with customer information, the second part considers relationship marketing factors and the third part measures components of customer's loyalty. Cronbach alpha in relationship marketing, loyalty and overall alpha were measured $0.878,0.891$ and 0.712 , respectively. They analyzed the data using LISREL software and ranked the components of the internal and external latent variables by using the Friedman test and reported that some components were not meaningful when the level of significance was five percent.

Darvish et al. (2013) investigated the effect of six factors on electronic banking including easy access, design, transaction speed, security, information content and customer support on customer satisfaction. They studied different branches located in north east of city of Tehran, Iran named Tejarat and selected a sample of 200 customers, designed, and distributed a questionnaire among them. The results of their survey indicated that all six components significantly influenced on customer satisfaction. Tajzadeh-Namin et al. (2012) made an assessment on the quality of services of Tehran's Saman bank and the available gap between customer's expectation and perception.

\section{Literature Review}

\subsection{Dimensions of service quality}

According to Parasuraman et al. (1998), service quality is the gap between customers' expectations and perceived performance of a service. In this regard, Kuo et al. (2009) developed SERVQUAL 
model as measure to examine service quality. SERVQUAL service quality includes 5 dimensions and 22 components.

\section{Tangibles}

- Modern equipment

- Considerable physical facilities

- Well-dressed employees

- Orderly documents (e.g. handouts, filing, invoices, etc.)

\section{Reliability}

- Providing the promised service in timely manner

- Sincerity in solving customer problems

- Improvement in services as soon as possible

- Providing the service as promised

- Delivering accurate reports

\section{Responsiveness}

- Employees let the customers know what services they will actually provide

- Employees provide customers with immediate services (as soon as possible)

- Employees are always willing to help customers

- Employees are always available to answer customer questions

\section{Assurance}

- Employees' behavior will gradually engender customer trust

- Customers feel confident in their interaction with the organization

- Employees are always polite to customers

- Employees have enough knowledge to answer customer questions

\section{Empathy}

- Individual concern for customers

- Adequate business hours for all customers

- Employees treat customers with special attention

- Employees wish the best of benefits for customers

- Employees perceive customers' special needs( Jose \& Laura ,2010)

\section{Customer loyalty}

Traditionally, loyalty refers to adherence to ideology but it has lately been used to business culture to characterize customers' enthusiasm for continuous work with a firm, exclusive purchase of its products and services and voluntarily recommending these products and services to friends and colleagues. Customer loyalty would remain as long as customers under the impression they are getting better services than otherwise will be offered by other providers. Therefore, customers tend to buy products or services based on what they think will give them the highest value. The highest value is associated with the difference between the total value demanded by the customer and the total expenditure they pay for the product or service (Grönroos, 2009), Oliver offered a rather comprehensive definition of customer loyalty as the commitment to buy or to select the same product or service continuously in future purchases though situational impacts and marketing efforts may potentially change customer behavior. 
In the realm of services, loyalty is broadly defined as the observed behaviors. However, behavioral scales such as repeat purchase have been criticized because of insufficient conceptual basis and offering a narrow scope of a dynamic concept. Thus, behavioral view towards loyalty cannot offer a comprehensive view of the main reasons of loyalty. In return, customers' view in terms of preferences or tendencies plays essential role in their loyalty. Therefore, repeat purchase may not be even based on preferences rather it could be because of some limitation, which prevent customer loss. In this regard, customer loyalty is considered as an attitudinal structure. In addition to behavioral and attitudinal views towards customer loyalty, cognitive view has also been introduced. The operational definition of cognitive view centers on the very first product or service coming into the customer's mind once they make a decision to purchase things or on the very first product or service they may choose from among other products or services (Landrum et al., 2007; Faghihi et al., 2007).

\section{The stages of building customer loyalty}

Oliver has delineated four stages of building customer loyalty as follows:

1. Cognitive loyalty: At this stage, the available data presents the advantage of an offering over other alternatives. This stage of loyalty centers on customer beliefs. Customers build their own knowledge based on previous experiences.

2. Affective loyalty: Customers' behaviors towards the organization are influenced by the level of satisfaction with previous experiences. At this stage, customers' satisfaction reflects their own happiness. Commitment refers to this stage of affective loyalty. This stage of loyalty is stronger than the previous one; however, as with the previous stage, there is the vulnerability of customers' switching to some competitive offerings because evidence has stated that a high percentage of customers who leave the firm claim to be satisfied with its offerings.

3. Conative loyalty: This stage is associated with an impulse to intend a behavior. The impulse indicates commitment to repeat buy. This commitment is associated with the customers' intent to repeat purchase and resembles the impulse. Although customers' intent to repeat purchase could be forecasted.

4. Action loyalty: This is associated with the study of mechanisms whereby intentions are put into effect. In the sequences of action control, the intentions developed during previous stages could be translated into readiness to do action. This pattern is accompanied by additional desire to overcome the barriers deterring the action. Consequently, action is the necessary result of the three previous stages (Ueltschy et al., 2007; Vesel \& Zabkar, 2009).

\section{Materials and methods}

The method of research is descriptive correlation with a survey design. The population of the study consisted of all customers of Bank Melli located in province of Golestan, Iran. Using Kerjesi-Morgan table and through simple random sampling, a number of 384 customers were selected as the participants of the study. SERVQUAL scale and a researcher-made questionnaire were used to examine service quality and customer loyalty, respectively.

The validity of either scale was acknowledged by experts. The reliability of either questionnaire was estimated using Cronbach alpha formula. In this regard, the reliability indices for the subscales of SERVQUAL questionnaire included: tangibles (0.87), reliability (0.92), responsiveness $(0.81)$, assurance (0.78) and empathy (0.83). The reliability of researcher-made customer loyalty questionnaire was calculated to be $\alpha=0.91$. Using SPSS19 software, Pearson correlation formula was run to analyze the data. 


\section{Findings}

The following is the first hypothesis of this survey,

$\begin{cases}H_{0}: & \text { There is no significant correlation between the tangibles dimension and customer loyalty. } \\ H_{1}: & \text { There is a significant correlation between the tangibles dimension and customer loyalty. }\end{cases}$

Table 1 demonstrates the summary of Pearson correlation coefficient along with meaningful level.

Table 1

The summary of Pearson correlation coefficients

\begin{tabular}{llll}
\hline & & Tangibles & Customer loyalty \\
\hline Tangibles & Pearson correlation & 1 & 0.742 \\
& Sig (two-tailed) & & 0.000 \\
& N & 384 & 384 \\
\hline Customer loyalty & Pearson correlation & 0.742 & 1 \\
& Sig (two-tailed) & 0.000 & 384 \\
\hline
\end{tabular}

As shown in the Table 1, the correlation coefficient for hypothesis 1 was calculated to be 0.742 . Since the level of significance in this test equals $\mathrm{Sig}=0.000$, which is smaller than $\alpha=0.05$, there is a significant correlation between the two variables. Accordingly, $\mathrm{H}_{0}$ is rejected but $\mathrm{H}_{1}$ is supported. With regard to the positive value of this coefficient $(+)$, there is direct relationship between the two variables.

$\begin{cases}H_{0}: & \text { There is no significant correlation between the reliability dimension and customer loyalty. } \\ H_{1}: & \text { There is a significant correlation between the reliability dimension and customer loyalty. }\end{cases}$

Table 2

The result of Pearson correlation ratios

\begin{tabular}{llll}
\hline & & Reliability & Customer loyalty \\
\hline Reliability & Pearson correlation & 1 & 0.671 \\
& Sig (two-tailed) & & 0.000 \\
& N & 384 & 384 \\
\hline Customer loyalty & Pearson correlation & 0.671 & 1 \\
& Sig (two-tailed) & 0.000 & 384 \\
\hline
\end{tabular}

As shown in Table 2, the correlation coefficient for hypothesis 2 was calculated to be 0.671 . Since the level of significance in this test equals $\mathrm{Sig}=0.000$ which is smaller than $\alpha=0.05$, there is a significant correlation between the two variables. Accordingly, $\mathrm{H}_{0}$ is rejected but $\mathrm{H}_{1}$ is supported. With regard to the positive value of this coefficient $(+)$, there is direct relationship between the two variables.

$\left\{H_{0}\right.$ : There is no significant correlation between the responsiveness dimension and customer loyalty.

$H_{1}$ : There is a significant correlation between the responsiveness dimension and customer loyalty.

Table 3

The result of Pearson correlation ratios

\begin{tabular}{llll}
\hline & & Responsiveness & Customer loyalty \\
\hline Responsiveness & Pearson correlation & 1 & 0.691 \\
& Sig (two-tailed) & & 0.000 \\
& N & 384 & 384 \\
\hline Customer loyalty & Pearson correlation & 0.691 & 1 \\
& Sig (two-tailed) & 0.000 & 384 \\
\hline
\end{tabular}


As shown in the table, the correlation coefficient for hypothesis 3 was calculated to be 0.691 . Since the level of significance in this test equals $\mathrm{Sig}=0.000$ which is smaller than $\alpha=0.05$, there is a significant correlation between the two variables. Accordingly, $\mathrm{H}_{0}$ is rejected but $\mathrm{H}_{1}$ is supported. With regard to the positive value of this coefficient $(+)$, there is direct relationship between the two variables.

$\begin{cases}H_{0}: & \text { There is no significant correlation between the assurance dimension and customer loyalty. } \\ H_{1}: & \text { There is a significant correlation between the assurance dimension and customer loyalty. }\end{cases}$

\section{Table 4}

The result of Pearson correlation ratios

\begin{tabular}{llll}
\hline & & Assurance & Customer loyalty \\
\hline Assurance & Pearson correlation & 1 & 0.572 \\
& Sig (two-tailed) & & 0.000 \\
& N & 384 & 384 \\
\hline Customer loyalty & Pearson correlation & 0.572 & 1 \\
& Sig (two-tailed) & 0.000 & 384 \\
\hline
\end{tabular}

As shown in Table 4, the correlation coefficient for hypothesis 4 was calculated to be 0.572 . Since the level of significance in this test equals $\mathrm{Sig}=0.000$ which is smaller than $\alpha=0.05$, there is a significant correlation between the two variables. Accordingly, $\mathrm{H}_{0}$ is rejected but $\mathrm{H}_{1}$ is supported. With regard to the positive value of this coefficient $(+)$, there is direct relationship between the two variables.

$\left\{\begin{array}{l}H_{0}: \text { There is no significant correlation between the empathy dimension and customer loyalty. } \\ H_{1}: \quad \text { There is a significant correlation between the empathy dimension and customer loyalty. }\end{array}\right.$

\section{Table 5}

The result of Pearson correlation ratios

\begin{tabular}{llll}
\hline & & Empathy & Customer loyalty \\
\hline Empathy & Pearson correlation & 1 & 0.631 \\
& Sig (two-tailed) & & 0.000 \\
& $\mathrm{~N}$ & 384 & 384 \\
\hline Customer loyalty & Pearson correlation & 0.631 & 1 \\
& Sig (two-tailed) & 0.000 & 384 \\
\hline & $\mathrm{N}$ & 384 & 3 \\
\hline
\end{tabular}

As shown in Table 5, the correlation coefficient for hypothesis 5 was calculated to be 0.631 . Since the level of significance in this test equals $\mathrm{Sig}=0.000$ which is smaller than $\alpha=0.05$, there is a significant correlation between the two variables. Accordingly, $\mathrm{H}_{0}$ is rejected but $\mathrm{H}_{1}$ is supported. With regard to the positive value of this coefficient $(+)$, there is direct relationship between the two variables.

\section{Results and discussion}

Considering the fact that the present findings showed a significant correlation between service quality and customer loyalty and that the present study investigated different aspects of service quality for the proposed case study including reliability of services, service specificity, service professionalism, speed of service, service facilities, employees' physical appearance and behavior and their interest in offering service to the customers, it is recommended that the management of the proposed case study conduct periodical surveys to examine its customers' loyalty since customer needs are variable over the course of time. The employees need to dress up uniformly so that customers may judge their physical appearance as appropriate. 
A new research department may be established in the bank in order to study new banking services which may increase the diversity of this case study's services and specialty. Finally, it is recommended that employees be trained to shape similar behavior towards all customers. Banks may provide free counseling services for their customers about the plans proposed by the customers and use this service as an advantage in including or excluding the customers. Such services would be of bilateral value. On the one hand, counseling would help the customers make better decisions and thus take fewer risks. On the other hand, providing such services would increase loyalty in customers and reduce banking risks.

\section{Acknowledgment}

The authors would like to thank the anonymous referees for constructive comments on earlier version of this work.

\section{References}

Arasli, H., Mehtap-Smadi, S., \& Katircioglu, S. T. (2005). Customer service quality in the Greek Cypriot banking industry. Managing Service Quality, 15(1), 41-56.

Babakus, E., \& Boller, G.W. (1992). An empirical assessment of the SERVQUAL scale. Journal of Business Research, 24, 253-268.

Brady, M. K., \& Cronin Jr, J. J. (2001). Some new thoughts on conceptualizing perceived service quality: a hierarchical approach. The Journal of Marketing, 34-49.

Crosby, P. B. (1985). Quality without tears: The art of hassle-free management. New American Library.

Darvish, H., Moayeri, M., Faradonbe, M \& Naderifar, A. (2013). A survey on relationship between customer satisfaction and electronic banking features: A case study of Tejarat bank in Iran. Management Science Letters, 3(2), 425-430.

Faghihi, A., Afsharnezhad, A., \& Kheirandish, M. (2012). An empirical study on performance management: A case study of national Iranian oil Production Distribution Company. Management Science Letters, 2(7), 2435-2440.

Guo, X., Duff, A., \& Hair, M. (2008). Service quality measurement in the Chinese corporate banking market. International Journal of Bank Marketing, 26(5), 305-327.

Grönroos, C. (2001). Service management and marketing (Vol. 2). New York: Wiley.

Hakkak, M \& Zare, N. (2013). Evaluating the impact of relationship marketing components on customers' loyalty level: Evidence from Iran Khodro Corporation. Management Science Letters, 3(2), 519-526.

Kuo, Y. F., Wu, C. M., \& Deng, W. J. (2009). The relationships among service quality, perceived value, customer satisfaction, and post-purchase intention in mobile value-added services. Computers in Human Behavior, 25(4), 887-896.

Landrum, H., Prybutok, V. R., \& Zhang, X. (2007). A Comparison of Magal's service quality instrument with SERVPERF. Information \& Management, 44(1), 104-113.

Martínez, J. A., \& Martínez, L. (2010). Some insights on conceptualizing and measuring service quality. Journal of Retailing and Consumer Services, 17(1), 29-42.

Parasuraman, A., Zeithaml, V., \& Berry, L. (1985). A conceptual model of service quality and its implications for future research. Journal of Marketing, 49 (4), 41-50.

Parasuraman, A. (1998). Customer service in business-to-business markets: an agenda for research. Journal of Business \& Industrial Marketing, 13(4/5), 309-321.

Parasuraman, A., \& Grewal, D. (2000). The impact of technology on the quality-value-loyalty chain: a research agenda. Journal of the academy of marketing science, 28(1), 168-174.

Tajzadeh-Namin, A., Pilevary, N \& Tajzadeh-Namin, A. (2012). Measuring customer satisfaction using SERQUAL survey. Management Science Letters , 2(3), 933-938. 
Ueltschy, L. C., Laroche, M., Eggert, A., Bindl, U. (2007). Service quality and satisfaction: an international comparison of professional services perceptions. Journal of Services Marketing, 21(6), 410-423.

Vesel, P., \& Zabkar, V. (2009). Managing customer loyalty through the mediating role of satisfaction in the DIY retail loyalty program. Journal of Retailing and consumer Services, 16(5), 396-406. 